\title{
Simultaneous determination of seven glucocorticoids in cosmetics by liquid chromatography tandem mass spectrometry
}

\author{
Bui Quang Dong ${ }^{1 *}$, Vu Thi Phuong ${ }^{2}$, Tran Thi Van Anh ${ }^{2}$, Tran Cao Son ${ }^{1}$ \\ ${ }^{1}$ National Institute for Food Control, Hanoi \\ ${ }^{2}$ Vietnam University of Traditional Medicine, Hanoi
}

(Received: 16/4/2020; Accepted: 15/6/2020)

\section{Abstract}

A rapid high-performance liquid chromatography method with electrospray ionization and tandem mass spectrometry detection (LC-ESI-MS/MS) was developed and validated for the simultaneous determination of 7 glucocorticoids (GC) including hydrocortisone acetate (HCA), cortisone acetate (COA), prednisone (PDS), prednisolone (PDL), methyl prednisolone (MPL), dexamethasone (DEX) and fluocinolone acetonide (FLA), which may be illegally blended in transdermal cosmetics. Sample preparation step consists of the extraction with ethyl acetate followed by centrifugation and filtration. The extract was dried, diluted and cleaned using C18 SPE column. The compounds were separated by reversed-phase chromatography with mobile phase containing $0.1 \%$ formic acid in water and acetonitrile in gradient condition. The method was validated at the validation level from $0.12-6.0 \mu \mathrm{g} / \mathrm{g}$. The LODs for PDS, PDL and FLA were $0.3 \mu \mathrm{g} / \mathrm{g}$ and for the others were $0.03 \mu \mathrm{g} / \mathrm{g}$, and LOQs were 0.6 and $0.12 \mu \mathrm{g} / \mathrm{g}$, respectively. The reproducibility was satisfied with the relative standard deviation below $23 \%$ and the recoveries were in the range of $74.3-106.7 \%$ meeting the AOAC International requirements. The studied glucocorticoids were detected in about $20 \%$ of tested samples collected in Hanoi with the level contents in the range from $0.18-16.2 \mu \mathrm{g} / \mathrm{g}$.

Keywords: Glucocorticoids, cosmetics, LC-MS/MS, hydrocortisone acetate, cortisone acetate, prednisone, prednisolone, methyl prednisolone, dexamethasone, fluocinolone acetonide.

\section{INTRODUCTION}

Glucocorticoids are known to be highly effective drugs which have been widely used for the treatment of inflammatory diseases. In dermatology, they have been used for the treatment of skin disorders such as psoriasis, dermatoses. They reduce inflammation and can temporarily relieve the symptoms of inflammatory skin problems of severe plaque psoriasis [1-2]. For topical use, they are available in the forms of creams, gels, and ointments with different potency and efficacy.

Unfortunately, the use glucocorticoids may cause a number of side effects on human. Prolonged therapy with glucocorticoids preparations will result in adverse effects like skin atrophy, cutaneous reactivity and some systematic side effects, hypertension, diabetes mellitus, osteoporosis, allergic contact dermatitis, Cushing's syndrome, and so forth [6-7].

For this reason, cosmetic products should not contain glucocorticoids. The agreement on the ASEAN harmonized system in cosmetic management states that glucocorticoids are among the prohibited substances used in cosmetics [8]. Therefore, there is a need for an analytical method for rapid screening of cosmetic products such as creams, ointments, and gels, which may illegally contain glucocorticoids for whitening purpose of cosmetics. 
Earlier studies reported a number of different LC methods for these steroids in biological matrices or pharmaceutical formulations. In the ASEAN agreement, substances of the glucocorticoids group in cosmetic products determined by HPLC-DAD obtain LOD values of 20-50 $\mu \mathrm{g} / \mathrm{g}$; LOQ from 70-160 $\mu \mathrm{g} / \mathrm{g}$ [8]. The study of Jelena B. Golubović et al. used the liquid chromatograph-mass spectrometry method for the determination of undeclared glucocorticoids in cosmetic creams. Eleven glucocorticoids including prednisolone, methylprednisolone, prednisolone-21-acetate, fluocinolone acetonide, fluocinolone acetonide-21-acetate, hydrocortisone-21-acetate, dexamethasone, betamethasone, betamethasone dipropionate, clobetasol propionate and triamcinolone were examined. Good separation by using a gradient-elution LC-MS/MS method with run time of 25 min enabled the use of a segmented detection method and consecutive decrease in detection limits. The proposed method has been validated in the linearity range of $10-1000 \mathrm{ng} / \mathrm{mL}$ with coefficients of determination higher than 0.990 . The method LOQs ranged from 0.75 - 3.0 ng/mL [10]. In 2018, Nguyen Quoc Tuan and Chau Minh Vinh Tho developed method to detect 4 glucocorticoids including dexamethasone, betamethasone, prednisolone and triamcinolone in cosmetics [4]. In 20 products collected in Tra Vinh, Vietnam, there was $35 \%$ of those containing glucocorticoids adulterated with glucocorticoids. Chau Minh Vinh Tho has published method to determine 4 glucocorticoids (HCA, DEX, BM and PSL) in cosmetics with LOD: $0.013-0.07 \mu \mathrm{g} / \mathrm{g}$, LOQ: $0.04-0.22 \mu \mathrm{g} / \mathrm{g}$ ). On preliminary practical application, these four adulterant glucocorticoids in 34 cosmetic products using in treating acnes and whitening skin collected at Can Tho city were investigated. Of these, $11.7 \%(4 / 34)$ of the ones were detected to be adulterated with corticosteroids [4]. Le Thi Huong Hoa analyzed 12 glucocorticoids adulterated in cosmetics in 2013, there is $3 / 11$ samples positive with glucocorticoids [5]. Because of high sensitivity and selectivity, LC-MS/MS was employed to detect and quantify glucocorticoids in cosmetics.

ASEAN harmonized method for glucocorticoids using TLC or HPLC may results in fault positive because of the limited specificity. In this study, seven common substances which was detected from previous studies have been selected for the simultaneous detection and quantification using LC-MS/MS [11].

\section{MATERIALS AND METHODS}

\subsection{Standards and Chemicals}

Glucocorticoids standards, with higher than 95\% purity, including hydrocortisone acetate (HCA), cortisone acetate (COA), prednisone (PDS), prednisolone (PDL), methylprednisolone (MPL), dexamethasone (DXM)) and fluocinolone acetonide (FLA) were purchased from TRC, Germany.

Ethyl acetate, diethyl ether, chloroform, dichloromethane, methanol, acetonitrile and formic acid 99.9\% were purchased from Merck, Germany. Oasis HLB (60 mg, $3 \mathrm{~mL}$ ) and SPE - C18 (500 mg, $3 \mathrm{~mL}$ ) were obtained from Waters. Distilled water was produced by an Aquatron system (ST15 OSA, UK).

\subsection{Chromatographic conditions}

The analytical method used Shimadzu 20AD liquid chromatography combined with triple quadrupole mass spectrometry SCIEX 5500 QQQ. Chromatographic separation was obtained employing Acquity UPLC BEH C18 column $(2.1$ x $50 \mathrm{~mm}, 1.7 \mu \mathrm{m})$. The LC eluents were acetonitrile (A) and $0.1 \%$ formic acid in water (B). The gradient was initiated with $10 \%$ eluent $\mathrm{A}$ and $90 \%$ eluent B for $1.5 \mathrm{~min}$, continued with linear variation to $90 \% \mathrm{~A}$ and $10 \% \mathrm{~B}$ in 2.5 
min. This condition was maintained for $2.5 \mathrm{~min}$ and returned to $10 \% \mathrm{~A}$ and $90 \% \mathrm{~B}$. Total analysis time for one injection was 7 mins. The flow rate was $0.3 \mathrm{~mL} / \mathrm{min}$ and the injection volume was $5 \mu \mathrm{L}$.

\subsection{MS condition}

Each group of analytes which belonged to a specific segment was dissolved in methanol at concentration of $1.0 \mu \mathrm{g} / \mathrm{mL}$ and infused into the ESI source and then MS parameters were optimized using the MRM optimization option. Optimization for the yield from collision energy was automatically performed by the instrument control software. ESI in positive ion mode was selected for the mass spectral analysis. ESI parameters optimized were as follows: Ionspray Voltage (IS) 5.500V; temperature $550^{\circ} \mathrm{C}$; Curtain Gas (CUR) 25 psi; Collision gas (CAD) 8 psi; Ion source gas 1 (GS1) 45 psi; Ion source gas 2 (GS2) 45 psi.

\subsection{Sample preparation}

A homogenized sample portion of $1.0 \mathrm{~g}$ was accurately weighed into a $50 \mathrm{~mL}$ extraction tube. The sample was extracted with $5 \mathrm{~mL}$ of water and $10 \mathrm{~mL}$ of ethyl acetate by mixing for $30 \mathrm{~s}$ using vortex mixer and shaking for 1 minute using rotary shaker. The solution was then centrifuged for $5 \mathrm{~min}$ at $6.000 \mathrm{rpm}$. Collect the ethyl acetate layer into $20 \mathrm{~mL}$ volumetric flask. Repeat the extraction one more time with $10 \mathrm{~mL}$ ethyl acetate and the combined extract was made up to $20 \mathrm{~mL}$. $1 \mathrm{~mL}$ extract was then dried under nitrogen stream and the residue was reconstituted in $1 \mathrm{~mL}$ of acetonitrile. Oil-based excipients in cream extract are removed with $0.5 \mathrm{~mL}$-hexane. $1 \mathrm{~mL}$ of gel and cream extract was diluted with $10 \mathrm{~mL}$ waters before clean up via solid phase extraction (SPE) step. SPE procedure was followed $3.0 \mathrm{~mL}$ methanol and 3.0 $\mathrm{mL}$ water for activation. Extract was then loaded into C18 column before washed with methanol $30 \%$. The analytes were eluted with methanol before being analyzed by LC-MS/MS.

\subsection{Method validation}

The method was then validated for specificity, linearity, matrix effect, limit of detection (LOD) and limit of quantification (LOQ), repeatability and recovery according to the EU requirements in EC/657/2002. The specificity was investigated by analyzing blank, spiked sample and standard. The matrix-matched calibration solutions were from 10 to $200 \mathrm{ng} / \mathrm{mL}$ equal from $0.12-6,0 \mu \mathrm{g} / \mathrm{g}$. The matrix effect was evaluated by comparing slopes of matrix - matched calibration curve to those of solvent calibration curve and expressed in percentage. The LOD and LOQ were attained by signal to noise ratio $(\mathrm{S} / \mathrm{N})$ methodology. The LOD and LOQ were determined by blank-spiked samples at low concentrations which gave $\mathrm{S} / \mathrm{N}$ equal to 3 and 10, respectively. All the samples were performed in triplicates. The recovery and repeatability were assessed at three concentration levels (10, 100 and $200 \mathrm{ng} / \mathrm{mL})$ according to EC/657-2002 for method validation.

\subsection{Application for screening of glucocorticoids in cosmetics}

The validated method was applied for the determination of studied glucocorticoids in 20 cosmetics samples which were randomly purchased from local markets in Hanoi.

\section{RESULTS AND DISCUSSION}

\subsection{MS/MS condition optimization}

The mass transitions and optimum collision energy parameters, which are automatically optimized by Analyst 1.7 Software, are given in Table 1. 
Table 1. Parameters for ESI source and MRM acquisition of the glucocorticoids in cosmetics

\begin{tabular}{|c|c|c|c|c|}
\hline Glucocorticoid & $\begin{array}{c}\text { Precursor ion } \\
(m / z)\end{array}$ & $\begin{array}{c}\text { Product ion } \\
(m / z)\end{array}$ & $\begin{array}{c}\text { Collision energy } \\
(\mathrm{eV})\end{array}$ & Application \\
\hline \multirow[t]{2}{*}{$\mathrm{COA}$} & 403 & 343 & 27 & Quantitative \\
\hline & & 163 & 33 & Qualitative \\
\hline \multirow[t]{2}{*}{$D E X$} & 393 & 355 & 17 & Quantitative \\
\hline & & 373 & 17 & Qualitative \\
\hline \multirow[t]{2}{*}{$H A D$} & 405 & 327 & 31 & Quantitative \\
\hline & & 309 & 29 & Qualitative \\
\hline \multirow[t]{2}{*}{$F L A$} & 453 & 413 & 17 & Quantitative \\
\hline & & 433 & 15 & Qualitative \\
\hline \multirow[t]{2}{*}{$P D N$} & 359 & 341 & 17 & Quantitative \\
\hline & & 147 & 35 & Qualitative \\
\hline \multirow[t]{2}{*}{$P D L$} & 361 & 343 & 15 & Quantitative \\
\hline & & 147 & 31 & Qualitative \\
\hline \multirow[t]{2}{*}{$M P L$} & 375 & 253 & 15 & Quantitative \\
\hline & & 161 & 30 & Qualitative \\
\hline
\end{tabular}

Chromatograms of seven glucocorticoids were shown in Figure 1. Each analyte has been optimized with one precursor and two product ions. Precursor ion is selected from molecular mass, in the form of $[\mathrm{M}+\mathrm{H}]^{+}$. One transition was for quantitation and the other was for confirmation.
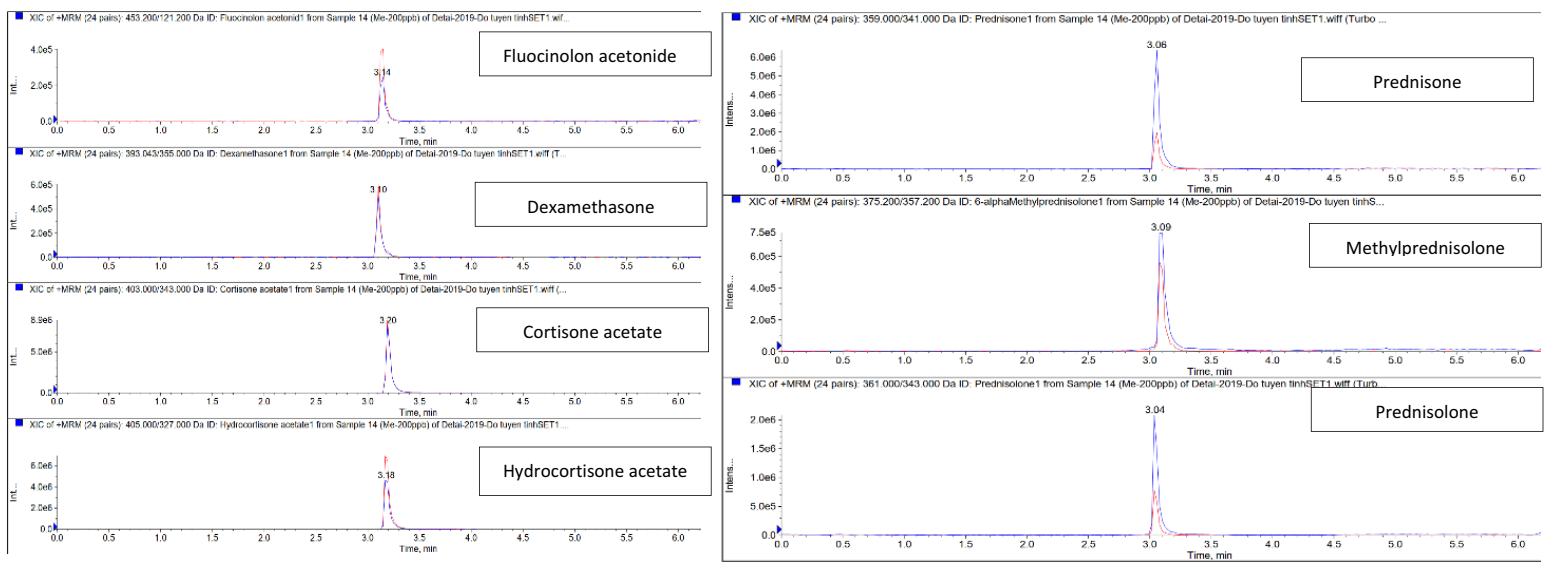

Figure 1. Chromatograms of 07 glucocorticoids of $100 \mathrm{ng} / \mathrm{mL}$ in methanol

\subsection{Investigation of extraction step}

Ethyl acetate, diethyl ether, dichloromethane and chloroform were chosen to investigate extraction efficiency of glucocorticoids in gel and cream matrices. $1.0 \mathrm{~g}$ of homogenous sample was weighted into a $50 \mathrm{~mL}$ extraction tube and spiked with $100 \mu \mathrm{g} / \mathrm{kg}$ glucocorticoids. After extraction, $1.0 \mathrm{~mL}$ extract was evaporated and reconstituted with $1 \mathrm{~mL}$ acetonitrile. Then $10 \mu \mathrm{L}$ extract was injected in to LC-MS/MS without clean-up. The extraction efficiency results of gel 
matrix are shown in Figure 2.

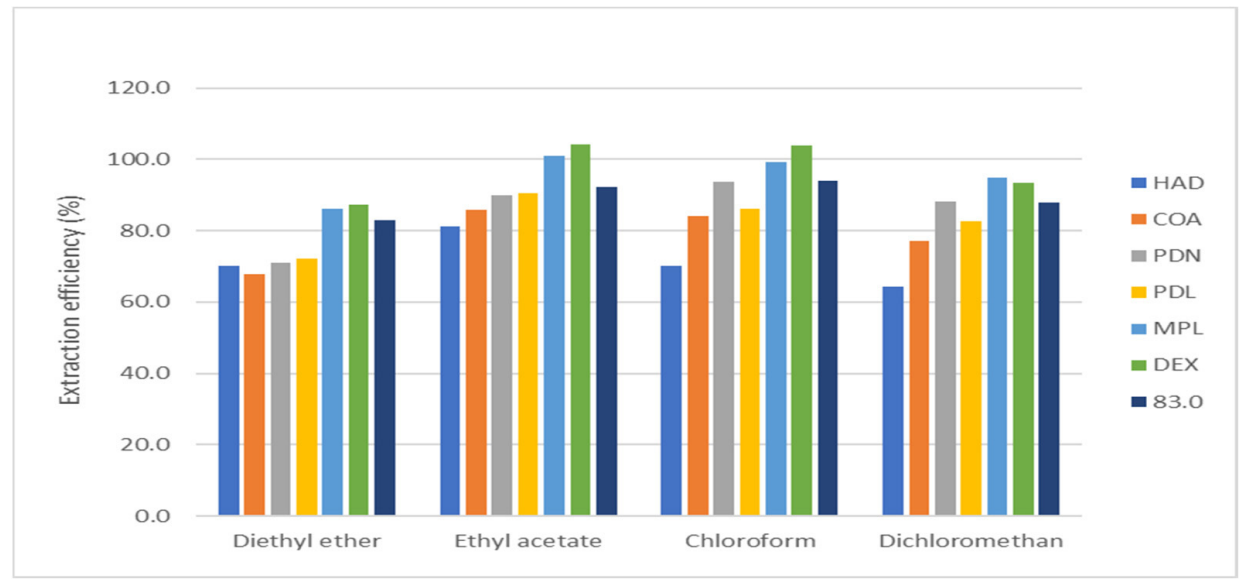

Figure 2. Extraction efficiency of different solvents in gel matrix

For gel matrix, ethyl acetate and chloroform show higher extraction efficiency compared to diethyl ether and dichloromethane. In contrast, no glucocorticoids have been detected in cream because of oil-based skeleton. Therefore, adding 5.0 mL water and shaking vigorously to break its bones and extract active compounds. Figure 3 showed results of using different solvents when extract glucocorticoids in cream matrix with the aid of water in extraction step.

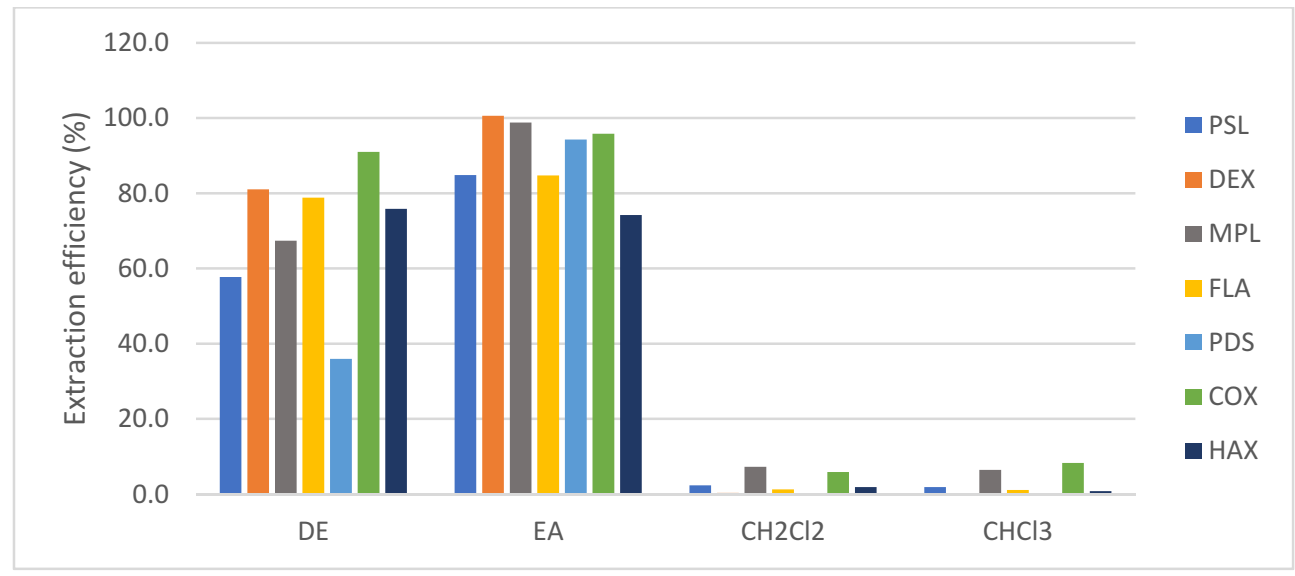

Figure 3. Extraction efficiency of different solvents for cream matrix

Extraction efficiencies data obtained from dichloromethane and dichloromethane were less than $10 \%$, which do not meet requirement for extraction. Using ethyl acetate was better than diethyl ether, as a result, ethyl acetate was chosen as the optimum solvent for extraction of seven glucocorticoids in cream matrix. Therefore, ethyl acetate was employed for extraction in both gel and cream matrix.

\subsection{Investigation of solid phase extraction (SPE)}

After extraction, $1.0 \mathrm{~mL}$ of ethyl acetate extract was evaporated and reconstituted in 1.0 $\mathrm{mL}$ acetonitrile. The extract was then diluted with water and cleaned-up through solid phase extraction step. C18 (500 mg, $3 \mathrm{~mL})$ and HLB (60 mg, $3 \mathrm{~mL}$ ) cartridges were evaluated through extraction efficiency shown in Figure 4. 


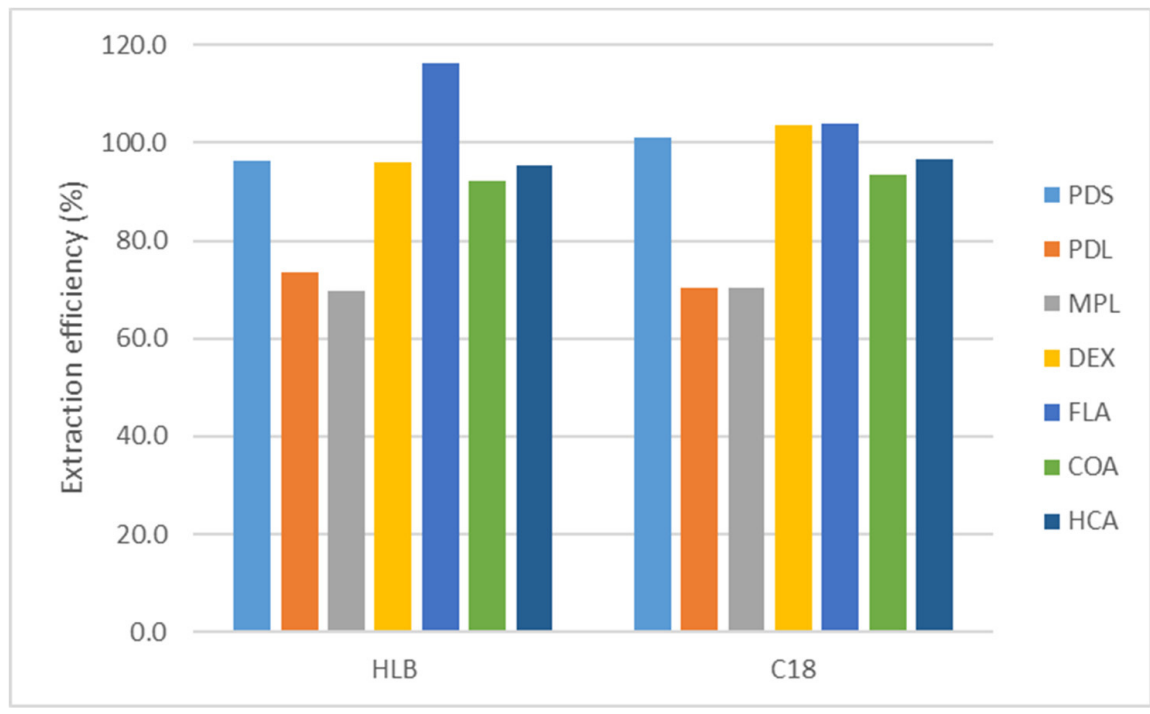

Figure 4. Solid phase extraction with HLB and C18 cartridge

Results showed no difference between extraction efficiencies of HLB and C18 cartridge. SPE-C18 column was chosen for further steps based on its availability and its lower cost.

To investigate the influence of methanol percentage on the elution of glucocorticoids from SPE-C18 cartridge, $1 \mathrm{~mL}$ of methanol in water in concentration from 0 to $100 \%$ used after elution. Chromatograms in Figure 5 indicated the effect of methanol concentration on elution of prednisolone on cartridge.
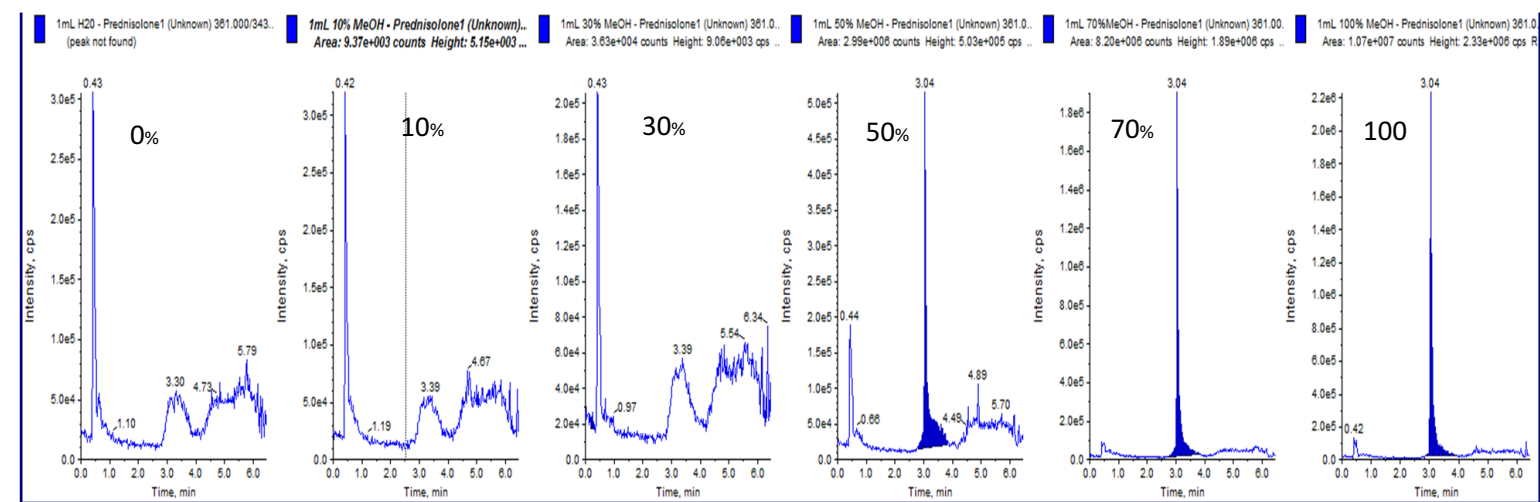

Figure 5. Chromatograms of elution of prednisolone by different concentration of methanol

Based on chromatograms in Figure 5, analyte signal appeared from $1.0 \mathrm{~mL}$ of methanol $50 \%$ elution. Signal of glucocorticoids in $100 \%$ methanol was highest. Therefore, $30 \%$ and $100 \%$ methanol were chosen as washing and eluting solvent for SPE step, respectively.

To investigate volume of washing and eluting solvent, each $1.0 \mathrm{~mL}$ of $30 \%$ and $100 \%$ methanol was added on cartridge containing $100 \mathrm{ng}$ each glucocorticoid and then analyzed by LC-MS/MS. There was no signal of glucocorticoids in all $3.0 \mathrm{~mL}$ of washing solvent, meanwhile glucocorticoids have been eluted from $\mathrm{C} 18$ cartridge completely after $3.0 \mathrm{~mL}$ of methanol. Therefore, $3.0 \mathrm{~mL}$ of $30 \%$ and $100 \%$ methanol was chosen as optimum volume for washing and eluting solvents of SPE.

The sample preparation was optimized by adding $5.0 \mathrm{~mL}$ water and duplicate extraction 
with $10 \mathrm{~mL}$ of ethyl acetate each time. $1 \mathrm{~mL}$ of extract was them evaporated and reconstituted by acetonitrile and diluted 10 times with water. The extraction was then loaded on SPE C18 cartridge and the analytes were washed with $3.0 \mathrm{~mL}$ of $30 \%$ methanol and eluted with $3.0 \mathrm{~mL}$ methanol before being analyzed by LC-MS/MS.

\subsection{Method validation}

The method specificity was investigated by the chromatograms illustrated in Figure 6, obtained from the blank, standard solution and the spiked sample.
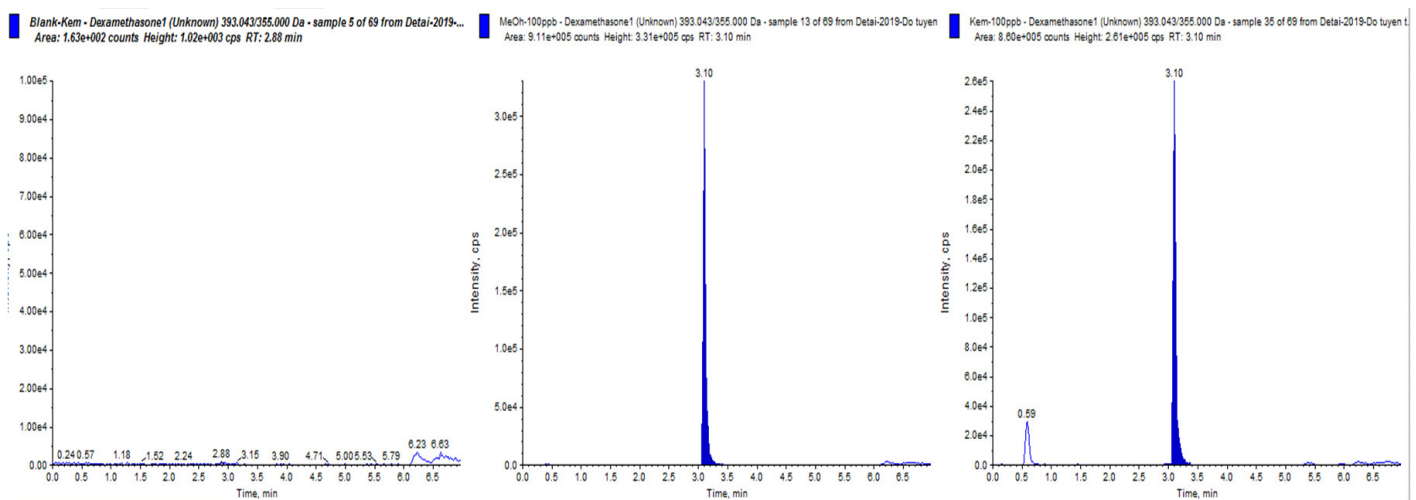

Figure 6. Chromatogram of dexamethasone in the blank, standard in a $10 \mu \mathrm{g} / \mathrm{L}$ solution and the spiked sample at $10 \mu \mathrm{g} / \mathrm{L}$

No interfering peaks at the retention time of the analytes were found in blank sample, standard solution and blank-spiked samples show Gaussian signal with the same retention time. Besides, one compound was determined by one quantitative parent/product ion and one confirmation parent/product ion, which gave 4.0 identification points for each compound satisfying EC/657/2002.

In Figure 7, Linearity was investigated within a concentration range from $10-200 \mu \mathrm{g} / \mathrm{mL}$. Good linearity was obtained from 10 to $200 \mathrm{ng} / \mathrm{mL}$ for all analytes with coefficients of determination $\left(\mathrm{R}^{2}\right)$ higher than 0.99 .

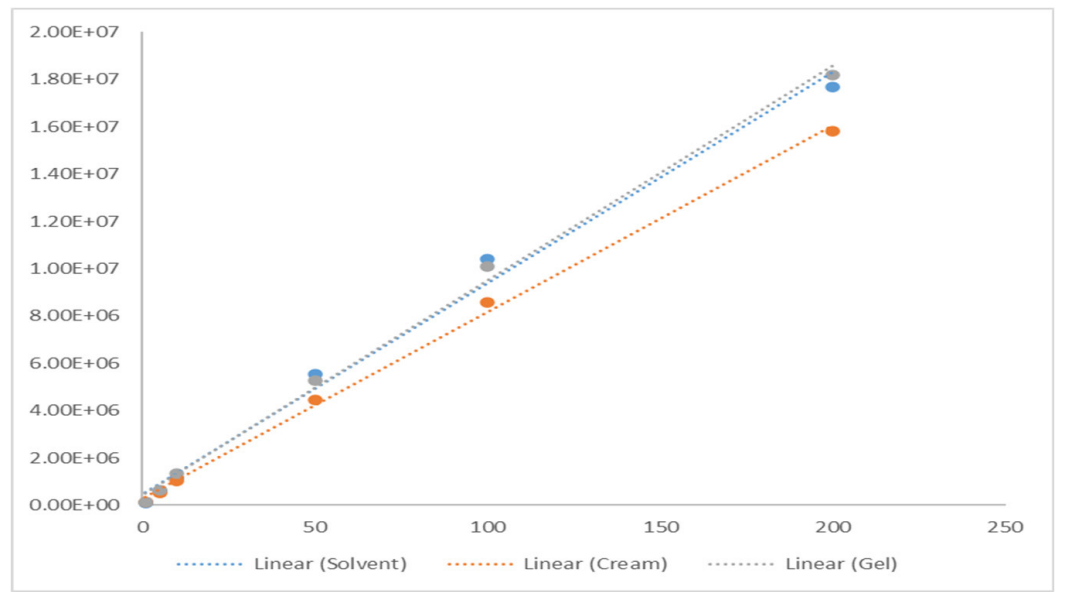

Figure 7. Calibration curve of hydrocortisone acetate in methanol and on matrix-matched extract

Matrix effect data has been obtained by ratio of slopes of matrix-matched calibration curves to those in methanol. The results were expressed in Figure 8. 


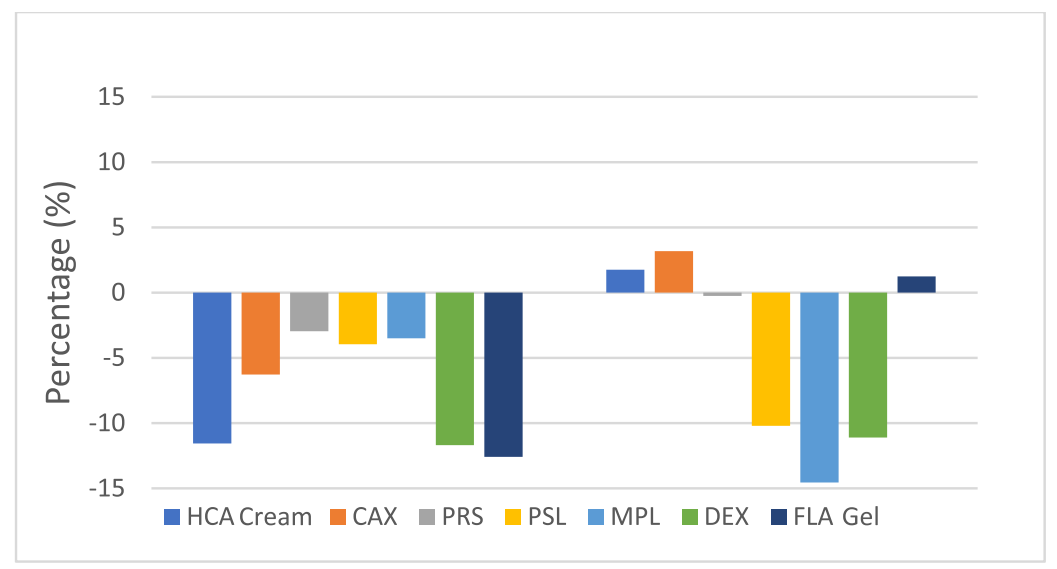

Figure 8. Matrix effects on glucocorticoids

Gel matrices had little effect on calibration curve of HCA, CAX, PRS and FLA meanwhile had great influence on slope of calibration curve of PSL, MPL and DEX. Cream has impact on slopes of HCA, DEX and FLA. Therefore, matrices-matched calibration curve is recommended for glucocorticoids quantitation in cosmetics.

Limit of detection (LOD) and limit of quantitation (LOQ) were estimated as $0.03-0.3$ $\mu \mathrm{g} / \mathrm{g}$ and $0.12-0.6 \mu \mathrm{g} / \mathrm{g}$ in cream and gel for HCA COA, DEX and PDS, PDL, MPL and FLA, respectively. The sensitivity was low enough to determine GC in transdermal cosmetics whose concentration is normally more than $1.0 \mu \mathrm{g} / \mathrm{g}[11]$.
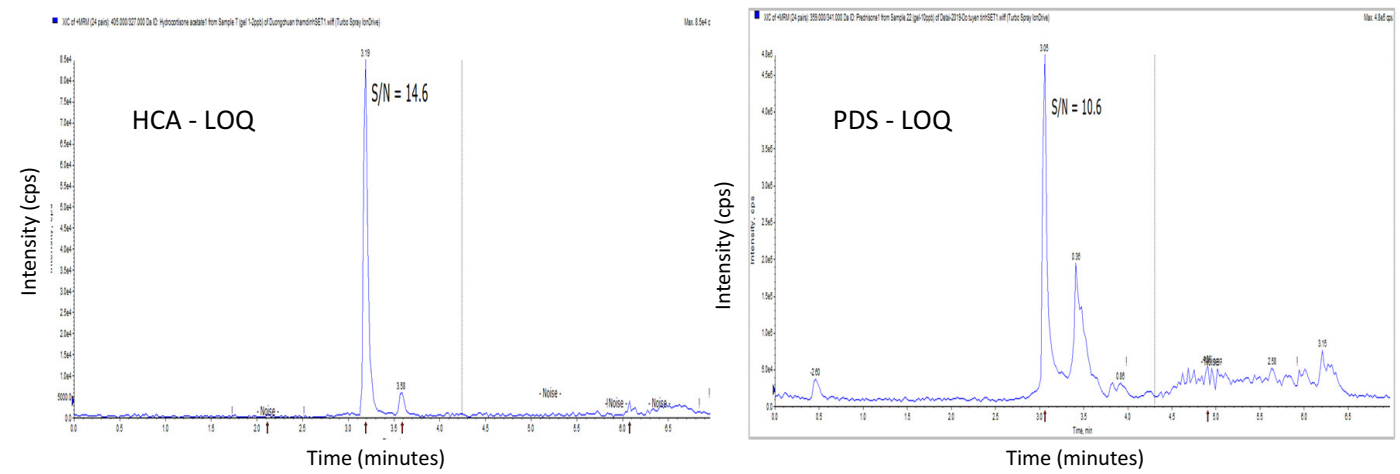

Figure 9. Chromatogram at LOQ of HCA cream at $0.12 \mu \mathrm{g} / \mathrm{g}$ and $P D S$ gel samples at $0.6 \mu \mathrm{g} / \mathrm{g}$

Result of recovery and repeatability of each glucocorticoid presented in Table 2.

Table 2. Recovery and repeatability of glucocorticoid

\begin{tabular}{lcccccc}
\hline \multirow{2}{*}{ Analytes } & \multicolumn{2}{c}{ Spk10 } & \multicolumn{2}{c}{ Spk100 } & \multicolumn{2}{c}{ Spk200 } \\
\cline { 2 - 7 } & Recovery (\%) & RSD (\%) & Recovery (\%) & RSD (\%) & Recovery (\%) & RSD (\%) \\
\hline HCA & 81.4 & 8.4 & 99.3 & 6.2 & 89.1 & 6.1 \\
$\boldsymbol{C A X}$ & 81.3 & 8.8 & 101.1 & 6.6 & 90.7 & 6.7 \\
$\boldsymbol{M P L}$ & 106.7 & 10.1 & 79.1 & 16.5 & 74.3 & 19.0 \\
$\boldsymbol{D E \boldsymbol { X }}$ & 90.4 & 13.9 & 104.3 & 5.4 & 93.7 & 6.0 \\
$\boldsymbol{F L A}$ & 89.9 & 17.0 & 104.7 & 6.6 & 93.4 & 7.6 \\
$\boldsymbol{P R S}$ & 94.4 & 14.4 & 92.7 & 9.7 & 95.9 & 9.8 \\
$\boldsymbol{P S L}$ & 101.2 & 15.5 & 87.1 & 7.4 & 93.5 & 8.1 \\
\hline
\end{tabular}

The repeatability was below $23 \%$ and recovery was in $74.3-106.7 \%$, met requirements 
in EC/657/2002. These results indicated that the method had an appropriate accuracy for quantitation of glucocorticoids in gel and cream cosmetics

\subsection{Analysis of cosmetic samples}

Twenty cosmetic products, intended for the treatment of atopic dermatitis or very dry skin, were analyzed using the developed and validated method. There are $04 / 16$ cream samples were positive for glucocorticoids, 04 gel samples were not detected GC with LOD of $0.03-0.3 \mu \mathrm{g} / \mathrm{g}$, which are presented in Table 3 . The result indicated that there is about $20 \%$ of tested products positive to glucocorticoids.

Table 3. Glucocorticoids content in detected cream samples

\begin{tabular}{cccccc}
\hline Samples & HCA $(\mu \mathrm{g} / \mathrm{g})$ & $\boldsymbol{C O A}(\mu \mathrm{g} / \mathrm{g})$ & $\mathrm{DEX}(\boldsymbol{\mu g} / \mathrm{g})$ & $\boldsymbol{F L A}(\mu \mathrm{g} / \mathrm{g})$ & $\begin{array}{c}\text { Sum } \\
(\mu \mathrm{g} / \mathrm{g})\end{array}$ \\
\hline $\boldsymbol{K} 04$ & - & 0.18 & 5.23 & - & 5.41 \\
$\boldsymbol{K} 08$ & 4.44 & 3.27 & - & - & 7.71 \\
$\boldsymbol{K} 12$ & $<\mathrm{LOQ}$ & - & - & 16.2 & $<16.3$ \\
$\boldsymbol{K} 13$ & - & - & $<\mathrm{LOQ}$ & - & $<0.12$ \\
\hline
\end{tabular}

\section{CONCLUSIONS}

An LC-MS/MS method for the simultaneous determination of low levels of seven topical glucocorticoids in cream and gel has been developed and validated. The proposed method enables analysis of seven glucocorticoids in cosmetic creams and gels. The method was carried out by liquid-liquid extraction with ethyl acetate and water (20/5) followed by cleaning up with solid phase extraction on C18 cartridge. All the requirements in EC-657/2002 for method validation have successfully met. LOD and LOQ of this method were enough to determine glucocorticoids in cosmetics. Consequently, the LC-MS/MS method was successfully applied in screening, confirmation and quantitation of glucocorticoid illegally blended in cosmetics for enhancing whitening effect. The results indicated that $20 \%$ of tested products detected glucocorticoids illegally blended.

\section{REFERENCES}

1. Mai Tất Tố, Vũ Thi Trâm, Dược lý học, Quyển. 2. Hà Nôi: Nhà xuất bản Y học, tr. 290-294, 2007.

2. Trần Đức Hậu, Hóa dược, Quyển. 2. Hà Nội: Nhà xuất bản Y học, tr. 510-511, 2014.

3. Nguyễn Quốc Tuấn và Đỗ Châu Minh Vĩnh Thọ, "Nghiên cứu xây dựng qui trình phân tích một số glucocorticoid ngụy tạo trong mỹ phẩm điều trị mụn, làm trắng da bằng phương pháp LC-MS-MS”, Tạp chi Dược học, số 502, tháng 2/2018, tr. 67-72, 2018.

4. Huỳnh Lâm Tú Anh và Đỗ Châu Minh Vĩnh Thọ, “Nghiên cứu xây dựng quy trình phân tích đồng thời một số glucocorticoid ngụy tạo trong mỹ phẩm làm trắng $\mathrm{da}$, điều trị mụn bằng phương pháp HPLC/PDA”, Tạp chí Dược học, số 515, tháng 3/2019, tr. 71-75, 2019.

5. Lê Thị Hường Hoa, "Nghiên cưu xây dưng quy trình phát hiện và xác định hàm lượng một số chất bị cấm sủ dụng trong mỹ phẩm”, Luận án tiến sĩ Dược học, Đại học Dược Hà Nội, 2013

6. S. Abrol, M. Wani and R.Harma, "Misuse of topical corticosteroids on facial skin", Department of Dermatology, Government Medical College, Jammu, India, 2017. 
7. F. A. Sendrasoa, I. M. Ranaivo, M. Andrianarison, O. Raharolahy, N. H. Razanakoto and L. S. Ramarozatovo, "Topical Corticosteroids for Cosmetic Purpose in Antananarivo, Madagascar", Department of Dermatology, University Hospital Joseph Raseta Befelatanana, Antananarivo, Madagascar, 2017.

8. Annexes of the ASEAN Cosmetic Directive, Annex III, Part 1, March, 2013.

9. V. Giaccone, G. Polizzotto, A. Macaluso, G.Cammilleri and V.Ferrantelli "Determination of Ten Corticosteroids in Illegal Cosmetic Products by a Simple, Rapid, and High-Performance LC-MS/MS Method", Published in International Journal of Analytical Chemistry, vol. 2017, no. $2,2017$.

10. J.B. Golubović, B.M. Otašević, A.D. Protić and M.L.Zečević, "Liquid chromatography/tandem mass spectrometry for simultaneous determination of undeclared corticosteroids in cosmetic creams", University of Belgrade-Faculty of Pharmacy, Department of Drug Analysis, Vojvode Stepe 450, Belgrade, Serbia, 2015.

11. B. Desmedt, E. Van Hoeck, V. Rogiers, P. Courselle, J. O. De Beer, K. De Paepe and E. Deconinck, "Characterization of suspected illegal skin whitening cosmetics", Journal of Pharmaceutical and Biomedical Analysis, vol. 90, pp. 85-91, 2014.

\title{
Xác định đổng thời một số glucocorticoid trong mỹ phẩm bằng sắc ký lơng khối phổ hai lần (LC-MS/MS)
}

\author{
Bùi Quang Đông1 , Vũ Thị Phương², Trần Thị Vân Anh², Trần Cao Sơn ${ }^{1}$ \\ ${ }^{1}$ Viện Kiểm nghiệm an toàn vệ sinh thực phẩm Quốc gia \\ ${ }^{2}$ Học Viện Y Dược Học cổ truyền Việt Nam
}

Tóm tắt

Phương pháp sắc ký lỏng hiệu năng cao kết hợp với đầu dò khối phổ ba tứ cực sử dụng kỹ thuật ion hóa phun điện tử (LC-ESI-MS/MS) để xác định và định lượng đồng thời 07 glucocorticoids gồm hydrocortisone acetate (HCA), cortisone acetate (COA), prednison (PDS), prednisolone (PDL), methylprednisolone (MPL), dexamethasone (DEX)) và fluocinolone acetonid (FLA) đã được xây dựng và thẩm định. Phương pháp có thể được sử dụng để xác định các glucocorticoid trộn trái phép trong mỹ phẩm dạng kem và dạng gel bôi. Các chất phân tích trong mẫu được chiết lặp với ethyl acetate, làm sạch bằng cột chiết pha rắn $\mathrm{C} 18$ và phân tích trên sắc ký lỏng khối phổ hai lần. Các hợp chất được phân tách bằng sắc ký lỏng pha đảo kết hợp với rửa giải gradient nồng độ: $0,1 \%$ acid formic trong nước và acetonitril. Giới hạn phát hiện và giới hạn định lượng cho PDS, PDL và FLA lần lượt là $0,3 \mu \mathrm{g} / \mathrm{g}$ và $0,6 \mu \mathrm{g} / \mathrm{g}$ và đối với những chất khác là 0,03 và $0,12 \mu \mathrm{g} / \mathrm{g}$. Độ lặp lại dưới $23 \%$ và độ thu hồi trong khoảng $80-110 \%$ đáp ứng yêu cầu Châu Âu theo EC-657/2002. Phương pháp được ứng dụng thành công để phân tích 20 mẫu mỹ phẩm trên thị trường Việt Nam. Kết quả cho thấy có khoảng $20 \%$ mẫu thử chứa glucocorticoid với nồng độ dao động từ 0,175 đến $16,2 \mu \mathrm{g} / \mathrm{g}$.

Tù khóa: Glucocorticoids, mỹ phẩm, LC-MS/MS, hydrocortisone acetate, cortisone acetate, prednisone, prednisolone, methyl prednisolone, dexamethasone, fluocinolone acetonide. 